University of Nebraska - Lincoln

DigitalCommons@University of Nebraska - Lincoln

Faculty Publications, Department of Psychology

Psychology, Department of

$12-1996$

\title{
The Right to a Family Environment for Children with Disabilities
}

Victoria Weisz

University of Nebraska-Lincoln, vweisz1@unl.edu

Follow this and additional works at: https://digitalcommons.unl.edu/psychfacpub

Part of the Psychiatry and Psychology Commons

Weisz, Victoria, "The Right to a Family Environment for Children with Disabilities" (1996). Faculty

Publications, Department of Psychology. 338.

https://digitalcommons.unl.edu/psychfacpub/338

This Article is brought to you for free and open access by the Psychology, Department of at DigitalCommons@University of Nebraska - Lincoln. It has been accepted for inclusion in Faculty Publications, Department of Psychology by an authorized administrator of DigitalCommons@University of Nebraska - Lincoln. 
Published in American Psychologist, $51: 12$ (December 1996), pp. 1239-1245; doi 10.1037/0003-066X.51.12.1239

Copyright (C) 1996 American Psychological Association. Used by permission. "This article may not exactly replicate the final version published in the APA journal. It is not the copy of record.” http://www.apa.org/journals/

A version of this article was presented at the Second International Interdisciplinary Study Group on Ideologies of Children's Rights,

May 14-18, 1994, Charleston, SC. Victoria Weisz was supported, in part, by National Institute of Mental Health

Postdoctoral Fellowship MH 5T32-16156 during the preparation of this article.

Special acknowledgment is extended to Gary B. Melton, whose support and encouragement have been greatly valued.

\title{
The Right to a Family Environment for Children with Disabilities
}

\author{
Victoria Weisz, Center on Children, Families and the Law, University of Nebraska-Lincoln \\ Alan J. Tomkins, Law/Psychology Program, University of Nebraska-Lincoln \\ Corresponding author: Victoria Weisz, Center on Children, Families and the Law, University of Nebraska-Lincoln, \\ 121 South 13th Street, Suite 302, Lincoln, NE 68588-0227; email vweisz@unlinfo.unl.edu
}

\begin{abstract}
To access services for children with disabilities, the children often have been required to leave their families of origin. However, social science evidence indicates that there are substantial psychological benefits for children to remain with their families whenever possible. The UN Convention on the Rights of the Child (UN General Assembly, 1989) supports policies and programs that enable children with disabilities to receive services without leaving their family environment. This article briefly reviews the social science literature and the UN. Convention, and it documents trends in US. law consistent with the implications of the scientific evidence and international consensus. The authors conclude that it is important for the federal government to maintain these progressive programs and policies even as responsibilities for social programs shift to the states.
\end{abstract}

$\mathbf{W}$ hat is a right to a family environment? What would be the result if such a right were taken seriously in policy planning for children? The recognition of a right to a family environment would provide guidance for planning even for children who do not have families who can care for them (e.g., a policy preference for foster families rather than institutions for children of abusive families). For children who do have families, the recognition of such a right would be still more powerful. Policies that separate children from their families would necessarily be replaced by those that maintain children within their families. Although the recognition of individual rights in the United States does not require government spending to enable the exercise of rights (Rust v. Sullivan, 1991), the establishment of the right to a family environment for children would mean that policies would need to reflect the priority of keeping children with their families.

This article focuses on a particular group of children, children with disabilities. Children with disabilities are a useful example to explore the policy implications of advancing a child's right to a family environment. We point out that for many years, when children with disabilities received services for their disabilities, they often were separated from their families. We note that recently there has been a shift toward serving these children in their homes and communities. We show that this shift is consistent with social science evidence suggesting that there are substantial psychological benefits for children to receive services in their homes and communities. The social science data and the trend toward home-based ser- vices are consistent with direction advocated in the U.N. Convention on the Rights of the Child (U.N. General Assembly, 1989). We then turn our attention to U.S. laws and policies and find that they too have been evolving in a direction consistent with the social science evidence and the international consensus. We conclude with a plea for ratification by the United States of the U.N. Convention on the Rights of the Child, because it would help to ensure that there will be no backtracking on the progress that has been made in the past 25 years in serving children with disabilities.

\section{The Change in Vision Regarding Services for Children With Disabilities}

Children with disabilities have represented a class of individuals for whom governmental policies have typically interfered with the child's place within his or her family (e.g., Agosta \& Melda, 1995). Before the advent of governmentsponsored programs, however, care to individuals with disabilities was generally provided within the family (Berkson, 1993). Unfortunately, this family-based care was available only to individuals who were fortunate enough to be born to wealthy families. During the 18th century, well-off children with disabilities were educated in their families and often eventually took their place in society when they became adults. Persons who did not have families that could care for them were relegated to life as beggars or in sordid institutions. Society did not view people with disabilities as entitled to the same rights and opportunities as others (Taylor, Knoll, Lehr, \& Walker, 1989). 
The next century saw dramatic progress in the treatment and education of people with physical and mental disabilities. Dozens of schools for blind, deaf, and mentally retarded children were established in Europe and the United States. Innovative techniques were used, resulting in huge successes. These modern interventions, however, generally involved removing children from their homes, so that they could be educated with others who had similar disabilities and who required similar educational methods (Berkson, 1993). Individuals with disabilities were seen to require specialized and segregated services (Taylor, Knoll, et al., 1989). By the beginning of the 20th century, the vast majority of U.S. children with disabilities were enrolled in special education day schools or longterm residential treatment facilities, although some home-visiting services, influenced by settlement house workers, were also available to children and their families (Levine \& Levine, 1970; Roberts, Wasik, Casto, \& Ramey, 1991).

The next major shift occurred after World War II, when a movement to "normalize" the lives of children with disabilities occurred. Institutions and segregated special education facilities were dismantled or kept for the most severely disabled. Three main factors contributed to the normalization movement (Berkson, 1993). First, Democratic movements (e.g., the U.S. civil rights movement and the women's movement) paved the way for individuals with disabilities, and their families, to assert their rights to equal access to the benefits of society (Drimmer, 1993). Second, scientific studies demonstrated both that children with disabilities could be effectively educated (mainstreamed) in the public school system and that children were harmed in their emotional development (young children in particular) by lengthy separations from their parents, particularly their mothers. Finally, it became apparent that educating and caring for children with disabilities in their families were far less costly than providing for them in institutions (Bradley, 1992).

Thus, the view that children with disabilities are better off within a family environment is not new. However, only recently has government been willing to provide services without requiring removal or segregation of children with disabilities. Part of this change was prompted by insights generated by social scientific research.

\section{Social Science Perspectives}

Three areas of social scientific research are relevant to a discussion of the value of a family environment for children with disabilities: (a) research about general characteristics of families of children with disabilities, (b) evaluation research on family or parent interventions for children with disabilities, and (c) research regarding factors that contribute to institutionalization of children with disabilities.

\section{Characteristics of Families of Children With Disabilities}

Historically, it was believed that families of children with disabilities were different in a number of negative ways from comparison families. According to Berkson (1993), the most prevalent beliefs were that families of children with disabilities experienced increased stress, more depression, and more marital difficulties. There is some evidence for these trends. A recent examination of divorce rates and income in a national sample of 25, 000 eighth-grade students found that $20 \%$ of parents of children with disabilities were divorced or separated, as compared with $15 \%$ of other parents, and that the annual income of families of children with disabilities was $\$ 4$, 000-\$5, 000 less than that of other families (Hodapp \& Krasner, 1995). Nonetheless, an overview of controlled studies suggests that many families of children with disabilities adapt quite successfully (Berkson, 1993; Bristol, Gallagher, \& Schopler, 1988; Spaulding \& Morgan, 1986). Studies that do demonstrate increased stresses for families of children with disabilities do not necessarily suggest debilitating stresses. For example, Breslau and Davis (1986), in a carefully controlled study, found that although $30 \%$ of mothers of children with disabilities reported depressive symptoms, compared with only $15 \%$ of mothers of children without disabilities, there were no differences in the rates of debilitating diagnosable psychological disorders between the two groups. Further, note that although mothers of children with disabilities may be distressed at a significantly higher rate than other mothers, $70 \%$ of these mothers did not report symptoms of such distress.

The best predictor of depressive symptoms in mothers is, not surprisingly, the extent of the child's needs for assistance (Breslau, Staruch, \& Mortimer, 1982). Similarly, among parents of children with mental retardation, the parents of the most severely limited children report the highest rates of distress (Pahl \& Quine, 1987). Furthermore, the functioning level of the child was the strongest predictor of child-related stress in a large survey of parents of children with disabilities (Boyce, Behl, Mortensen, \& Akers, 1991).

As might be expected, the research on siblings of children with disabilities provides a mixed picture. Although some siblings resent or feel burdened by their disabled brother or sister, others feel affection and responsibility for them (Zetlin, 1990). A study that compared 24 preschool-age siblings of children with disabilities with 22 preschoolers with siblings without disabilities found no differences between the groups in self-competence or empathy but found that the children whose siblings had disabilities were more aggressive (Lobato, Barbour, Hall, \& Miller, 1987). A longitudinal study of siblings of children with disabilities found that these siblings were, as a group, more unhappy and aggressive than their controls but that there were no differences in rates of diagnosable psychological problems (Breslau \& Prabucki, 1987). In contrast, another smaller study that compared children with siblings with disabilities with children with siblings without disabilities found no differences between the groups in behavior problems, social competence, or self-esteem (Bischoff \& Tingstrom, 1991).

In addition to the studies that have found some negative effects of a disability in the family, a number of other studies have found positive effects. For example, Abbott and Mer- 
edith (1986) found that $55 \%$ of their sampled families reported a closer and stronger family and $41 \%$ reported personal growth after the birth of a child with mental retardation. Further, Burton and Parks (1994) found that college students who were siblings of individuals with disabilities demonstrated significantly higher locus of control than students with siblings without disabilities. These researchers surmised that siblings of children with disabilities gain psychological strength from their experiences.

Thus, although there may be some evidence of negative effects on parental relationships, sibling relationships, or general family functioning for children with disabilities, there also is evidence of considerable positive impact for families.

Early studies of families of children with disabilities indicated that they experience severe social isolation. However, recent studies that have used more complex models of social support have found that families of children with disabilities are similar to comparison families in their family support networks, although they differ from comparison families in having smaller friendship networks (Kazak, 1987). Families with children with disabilities may not differ from comparison families regarding their help from relatives. However, their need for relative support is considerably greater than comparison families. A recent survey of 92 families of children with disabilities in eight states found that almost a third of the families received no help from relatives outside their household (Knoll, 1992). Thus, many families are clearly not receiving the help they need, even if they may be no more isolated from their relatives than are other families. Perhaps, because of these unmet needs, many families with disabled children develop a rich network of professionals who offer considerable support to them (Kazak, 1987). The availability of support to these families is critical, because social support appears to be positively related to better coping and less stress for families of children with disabilities (Bristol, 1984; Harris, Carpenter, \& Gill, 1988).

Unfortunately, the growing recognition that children with disabilities benefit from remaining with their families and that families require both formal and informal support to care for these children has occurred during a period of decreasing resources to families in general (Marcenko \& Meyers, 1991). Increased family mobility, smaller family size, more singleparent families, and more families with two working parents create obstacles for all families with children (Hernandez, 1995). Families who have the task of caring for a child who needs extraordinary care are particularly disadvantaged by the changing demographics of our time. Although it may not be obvious, education and income level may be more critical to adaptation than the number of parents in a household. A review of 15 research studies on single parents of children with disabilities found that after education and income were controlled for, the stress and adaptation levels were not different between single mothers and married mothers (Boyce, Miller, White, \& Godfrey, 1995). Still, these studies suggested that the vast majority of single mothers had less education and income than their married controls, so the challenges that face these smaller families in managing the care of a child with a disability remain daunting.

\section{Family-Focused Interventions}

A variety of interventions directed toward the parents or families of children with disabilities have been demonstrated to be effective in enhancing the child's individual development, helping the parents cope more effectively, and decreasing family stress. Interventions range widely, from informal home visitors to parent behavior modification training, and all appear to yield positive results (Barrera, Rosenbaum, \& Cunningham, 1986; Brown-Gorton \& Wolery, 1988; Girolametto, 1988; Harris et al., 1988; Harrold, Lutzker, Campbell, \& Touchette, 1992; Resnick, Armstrong, \& Carter, 1988). Direct cash subsidies to families that allow them to choose services or support that they might need also appear to be quite successful in reducing family stress (Agosta \& Melda, 1995; Melda \& Agosta, 1992). Thus, the goal of maintaining children with disabilities within their families appears to be possible, and family-focused interventions are clearly the means to achieve that goal. One study has yielded findings that suggest caution, however. Lower income, single-parent, and socially isolated families apparently are less able to maintain the gains from interventions over the long term, as compared with families with more resources (Harris et al., 1988). Program characteristics, however, seem to play a very significant role in parents' perceptions of personal control, whereas family demographics do not play such a role (Trivette, Dunst, Boyd, \& Hamby, 1995). Trivette and her colleagues found that interventions that were family centered, with parents having frequent contact with a caregiver using empowering caregiving practices, resulted in more personal control for all parents. Thus, services to families with few internal resources must be provided over the long term if they can be expected to maintain their effectiveness, and the more family centered the services are, the more likely parents are to feel a sense of control over their situation.

\section{Out-of-Home Placement}

There is little research about the factors that contribute to some parents deciding to place their children out of the home. One study of such placements for children with moderate to severe mental retardation suggested that most families make the decision to place their child rather quickly, after a buildup of child-related pressures over time rather than a single precipitating event. About a third of the parents noted child-related reasons for their decision; $23 \%$ cited reasons about themselves rather than their children (deteriorating health or change in job, finances, marital status, or marital adjustment; Blacher \& Baker, 1994). Another study interviewed 137 randomly selected families from an out-ofhome placement waiting list. Caregiver stressors were predictors of feelings of urgency for the out-of-home placement, but behavioral problems of the child were not (Kobe, Rojahn, \& Schroeder, 1991). 
There is little research directly exploring the link between the availability of family-directed services and decisions to place children out of the home. However, family-focused interventions appear to be successful at increasing the family's commitment to continued care in the home rather than seeking out-of-home placements (Parrott \& Herman, 1987). Nonetheless, many parents continue to place their children outside the home despite the evidence supporting in-home care and in spite of professionals encouraging families to care for their children at home (Bromley \& Blacher, 1991; Taylor, Lakin, \& Hill, 1989).

\section{Summary of Social Scientific Perspectives}

Although there are a number of unresearched areas regarding children with disabilities and their families, there are good data that exist. Families of children with disabilities experience more stress than other families, but the majority of these families do not experience debilitating stress. Furthermore, there are positive benefits to families of children with disabilities. Families in which there are children with disabilitiesparticularly families that have few internal resources due to poverty, single parenthood, or social isolation-appear to have strong needs for help, to enable them to adapt to the difficult circumstances and to care for their child. A variety of intervention programs appear to be quite successful in meeting those needs, as well as directly helping the child's development. These programs do not often result in long-term gains, however, especially for struggling families. Thus, interventions need to be comprehensive, long term, and family centered, if true assistance to these families is to be achieved. The likelihood of out-of-home placement of children appears to be reduced when family support is provided.

Thus, family-focused interventions appear to be necessary to help families with disabled children adapt to the challenges they face. These interventions also help keep children with disabilities in their families.

Keeping children in their homes is an idea that has found support in both international and national legal and policy contexts. Under both U.N.-based policy and legal developments and U.S. policy and legal developments, frameworks have been developed that are supportive of serving children with disabilities in their family environment. We next turn our attention to these legal and policy developments, beginning with the international (i.e., U.N.) activities and then turning to national actions.

\section{U.N. Convention on the Rights of the Child}

In 1989, after a decade of deliberation and development, the Convention on the Rights of the Child was adopted by the U.N. General Assembly (see Murphy-Berman \& Weisz, 1996, this issue). The preamble to the Convention makes it clear that all children have a right to a family environment because the family is the "natural environment" for the growth and well-being of children and that children should grow up in family environments to enable the "full and harmonious de- velopment" of their personalities (see Melton, 1996, this issue). Furthermore, Article 3 states that the best interests of the child shall be a primary consideration in all actions concerning children.

Article 23 of the U.N. Convention on the Rights of the Child (U.N. General Assembly, 1989) does not explicitly recognize the right of a child with disabilities to a family environment. ${ }^{1}$ Article 23 does acknowledge that a child with disabilities has the right to "enjoy a full and decent life, in conditions which ... facilitate the child's active participation in the community." Because a child's participation in the community typically arises from the child's participation in the family, we believe that Article 23 embodies the idea of a child's right to a family environment.

Further support for this position is found in the deliberations that took place before the final version of Article 23 was settled. The travaux preparatoires ${ }^{2}$ for Article 23 indicate that the delegation of the United Kingdom did introduce a provision directly acknowledging that the families of children with disabilities were in need of support (Detrick, 1992). This amendment reads as follows:

The States Parties to the present Convention recognize the right of mentally or physically handicapped children and their families to receive practical advice and support and the

\footnotetext{
${ }^{1}$ Article 23 of the U.N. Convention on the Rights of the Child provides
} for the following:

1. States Parties recognize that a mentally or physically disabled child should enjoy a full and decent life, in conditions which ensure dignity, promote self-reliance and facilitate the child's active participation in the community.

2. States Parties recognize the right of the disabled child to special care and shall encourage and ensure the extension, subject to available resources, to the eligible child and those responsible for his or her care, of assistance for which application is made and which is appropriate to the child's condition and to the circumstances of the parents or others caring for the child.

3. Recognizing the special needs of a disabled child, assistance extended in accordance with Paragraph 2 shall be provided free of charge, whenever possible, taking into account the financial resources of the parents or others caring for the child, and shall be designed to ensure that the disabled child has effective access to and receives education, training, health care services, rehabilitation services, preparation for employment and recreation opportunities in a manner conducive to the child's achieving the fullest possible social integration and individual development, including his or her cultural and spiritual development.

4. States Parties shall promote in the spirit of international cooperation the exchange of appropriate information in the field of preventive health care and of medical, psychological and functional treatment of disabled children, including dissemination of and access to information concerning methods of rehabilitation, education and vocational services, with the aim of enabling States Parties to improve their capabilities and skills and to widen their experience in these areas. In this regard, particular account shall be taken of the needs of developing countries.

${ }^{2}$ Travaux preparatories are the equivalent of the legislative history of international treaties or agreements. 
provision of a wide range of services to enable them to remain together and for handicapped children to live as independent and normal a life as possible in their community. (Detrick, 1992, p. 332)

The travaux does not clarify why this direct statement about children with disabilities and their families being entitled to receive support so that they can stay together was not retained in the further discussions and developments of the U.N. Convention (U.N. General Assembly, 1989). Article 23 does recognize the child's rights for available resources to those responsible for his or her care. This language could be used as a basis for arguments for resources to the parents of children with disabilities. It is unfortunate, however, that the direct statement of a child's need to stay with her or his family never made it into the final version of the Convention.

Still, the Convention (U.N. General Assembly, 1989) does offer considerable support for the notion that children with disabilities are entitled to interventions that keep them in their families. It is most clear in providing that

\begin{abstract}
ratifying countries [should] acknowledge the right of the [child with disabilities] to special care and ... extend resources and assistance, free of charge where possible, to the child's family. In particular, State Parties' assistance to [children with disabilities] should ensure effective access to education, training, health care and rehabilitative services. (Johnson \& McNulty, 1990, p. 229)
\end{abstract}

\section{U.S. Law Perspectives}

In the United States, there are six federal provisions that are relevant to in-home and in-community care for a child with disabilities, that help protect these children from discrimination, and that facilitate access to necessary physical and mental health care (Johnson \& McNulty, 1990; see Tomkins \& Weisz, 1995, for more details). These are the federal programs and laws that reflect U.S. conformity to Article 23's interest in a disabled child's right to "a full and decent life, in conditions which ensure dignity, promote self-reliance, and facilitate the child's active participation in the community" (Article 23 of the U.N. Convention on the Rights of the Child; U.N. General Assembly, 1989, Paragraph 1; Article 23 is reprinted in its entirety in footnote 1). The six U.S. legal provisions are (a) the Title V Maternal and Child Health Block Grant, ${ }^{3}$ (b) Medicaid, ${ }^{4}$ (c) Supplemental Security Income (SSI), ${ }^{5}$ (d) Section 504 of the Rehabilitation Act of $1973,{ }^{6}$ (e) the 1975 Education for Handicapped Children Act (later amended and renamed the Individuals With Disabilities Education Act; IDEA), ${ }^{7}$ and (f) the 1990 Americans with Disabilities Act (ADA). ${ }^{8}$

The Maternal and Child Health Block Grant provides funds for preventive and primary, prenatal and postnatal, health care for low-income mothers and children. Among its aims are the prevention of "handicapping conditions" and the promotion of child health. States are encouraged to establish "home visiting programs" and "related social support services" as part of their care programs (42 U.S.C. $§ 701$ [a] [1]; see, e.g., Albino v. Chicago, 1983).
Medicaid provides for prevention, primary, and intervention services for lower income children. It includes, but is not limited to, children with disabilities. One of its most important features is the "early and periodic screening, diagnostic, and treatment services" for children (i.e., anyone under 21 years; 42 U.S.C. $\S 1396 d$ [a] [4] [B] and $\S 1396 d$ [r] [5]; see, e.g., Miller v. Whitburn, 1993).

SSI provides for direct cash assistance (so that a minimum income level is obtained) to families of children with disabilities (42 U.S.C. $\S 1381$ ); the cash assistance is in addition to the Medicaid services indicated above. Under the U.S. Supreme Court's interpretation in Sullivan v. Zebley (1990), the SSI program is quite flexible in its eligibility criteria: A child is eligible for benefits if a disability interferes with the child's normal daily activities in comparison with a child without such disabilities. Relevant activities for determining eligibility include "speaking, walking, washing, dressing, and feeding oneself, going to school, playing" (Sullivan v. Zebley, 1990, p. 540).

The Rehabilitation Act of 1973 was the first major Congressional action to combat discrimination against persons with disabilities. The Rehabilitation Act makes it illegal to deny benefits to persons because of their disabilities or to otherwise discriminate against them (see, generally, Rothstein, 1992 /1994). Section 504 of the act (29 U.S.C. $§ 790$ ) is especially important, generally providing persons with disabilities the same rights that are extended to persons without disabilities. Some have suggested that the act is narrow because its jurisdiction only reaches to the context of federally funded programs or activities; nonetheless, it clearly encompasses "education programs; public facilities; transportation; and health and welfare services" implicated (Rothstein, 1992 /1994, p. 3). Moreover, the law's "net" is cast even wider because there are so many social programs that receive federal funding (see, e.g., Gittler \& Rennert, 1992). Thus, the Rehabilitation Act, both as a matter of history and as a matter of substantive law, is one of the most important pieces of legislation enacted by Congress to aid persons with disabilities.

The 1975 Education for Handicapped Children Act has become even more important. The act was passed in reaction to court decisions that lamented the fact that millions of students with disabilities were not being offered appropriate educational services (see Mills v. Board of Education, 1972; Pennsylvania Association for Retarded Children [PARC] v. Pennsylvania, 1971; see, generally, Rothstein, 1988). The law's name was changed to the IDEA (20 U.S.C. $\S 1400$ [a]); the

\footnotetext{
${ }^{3}$ Maternal and Child Health Services Block Grant, Title V of the Social Security Act, 42 U.S.C. $\S \S 701$ et seq .

${ }^{4} 42$ U.S.C. $\S 1396$ et seq .

542 U.S.C. $\$ \S 1381$ et seq .

629 U.S.C. $\S \S 790$ et seq .

${ }^{7} 20$ U.S.C. $\S \S 1400$ et seq .

842 U.S.C. $\S \S 12101$ et seq .
} 
law also was significantly amended several times in the past decade, most recently in 1994. The IDEA provides for a free and appropriate public education and related services that allow a child to make use of the educational services that are provided (see, e.g., Board of Education v. Rowley, 1982; Irving Independent School District v. Tatro, 1984). Included among the related services are psychosocial and medical interventions, and they can begin as early as birth (see, e.g., Vincent \& Salisbury, 1988).

Especially notable are the IDEA provisions for family-focused services (Hutchins \& McPherson, 1991; Vincent \& Salisbury, 1988). An Individualized Family Service Plan is provided for in instances in which there is a child with disabilities under the age of 3 . The newly enacted amendment to IDEA, the Families of Children With Disabilities Support Act of 1994 (20 U.S.C. § 1491a et seq.), is intended to allow children with disabilities to receive in-home (or, at least, in-community) care.

The 1990 ADA has been termed the nation's "most significant disability rights statute" and "the most significant civil rights legislation in 25 years" (Rothstein, 1992 /1994, pp. 10 \& 18). It is intended to provide persons with disabilities the whole gamut of civil rights available to citizens without disabilities (see, generally, Gostin \& Beyer, 1993). Although it is not yet clear what the actual impact of the law will be because it is of such recent vintage, it is possible that it will be extensive. Children with disabilities should be extensive beneficiaries. Under the ADA, "children with disabilities should be protected from the kinds of overt, subtle, and covert forms of discrimination that plague many groups in our society. ... The spirit of the ADA seems quite compatible with the kinds of family-friendly policies found in IDEA" (Tomkins \& Weisz, 1995, p. 954).

These statutes, especially when considered together, provide a strong foundation in American law for establishing the rights to be free from discrimination and for addressing the needs of children with disabilities (see, e.g., Kramer, 1994, chaps. 26, 31-33; Rothstein, 1992, 1994). Taken together, they also appear to embody the provisions and the spirit of Article 23 of the U.N. Convention on the Rights of the Child (U.N. General Assembly, 1989; see Tomkins \& Weisz, 1995).

\section{Conclusion}

Current U.S. laws and policies comport with Article 23 of the U.N. Convention on the Rights of the Child (U.N. General Assembly, 1989) in providing financial and programmatic assistance to families of children with disabilities. These national and international legal provisions reflect the social scientific evidence and contemporary public belief that families are the optimum environment for children with disabilities in most instances and that most families do a better job for their children if support is available to them.

There exist sufficient data to argue for the continued support for programs and policies that allow parents to care for their children in their homes. "Millions," wrote Agosta and Melda (1995, p. 279), "are still being spent on out-of-home services" but "relatively little [is] invested in families."

The next several years will quite likely see the responsibility and the costs for providing services to families shifting from the federal government to the states (see Agosta \& Melda, 1995). It remains to be seen whether this shift will create opportunities for states to more flexibly and creatively assist families of children with disabilities or whether it will result in the dismantling of programs designed to do so. Safety net policies, which have been put in place over the last two decades, that support the right of a child with disabilities to his or her family environment may be vulnerable.

This vulnerability would be tempered if there were strong legal provisions underscoring the right to a family environment for children, both as a general matter and particularly in the context of children with disabilities. It is unfortunate that as of this writing, the United States has not ratified the U.N. Convention on the Rights of the Child (U. N. General Assembly, 1989). If the Convention were ratified, it could be used as an instrument to protect the gains that have been made in protecting the place of children with disabilities in their family environments. Ratification would give this laudable, international legislation legal status in the United States. Without ratification, the Convention simply serves both as a beacon for what we should stand for and an embarrassment that our nation has not seen fit to join the rest of the world in recognizing it.

\section{REFERENCES}

Abbott, D. A., \& Meredith, W. H. (1986). Strengths of parents with retarded children. Family Relations, 35, 371-375.

Agosta, J., \& Melda, K. (1995). Supporting families who provide care at home for children with disabilities. Exceptional Children, 62, 271-282.

Albino v. Chicago 578 F. Supp. 1487 (N.D. Ill. 1983).

Barrera, M. E., Rosenbaum, P. L., \& Cunningham, C. E. (1986). Early home intervention with low-birth-weight infants and their parents. Child Development, 57, 20-33.

Berkson, G. (1993). Children with handicaps: A review of behavioral research. Hillsdale, NJ: Erlbaum.

Bischoff, L. G., \& Tingstrom, D. H. (1991). Siblings of children with disabilities: Psychological and behavioral characteristics. Counseling Psychology Quarterly, 4, 311-321.

Blacher, J., \& Baker, B. L. (1994). Out-of-home placement for children with retardation: Family decision-making and satisfaction. Family Relations, $43,10-15$.

Board of Education v. Rowley 458 U.S. 176, (1982)

Boyce, G., Behl, D., Mortensen, L., \& Akers, J. (1991). Child characteristics, family demographics and family processes: Their effects on the stress experienced by families of children with disabilities. Counseling Psychology Quarterly, 4, 273-288.

Boyce, G., Miller, B. C., White, K. R., \& Godfrey, M. K. (1995). Single parenting in families of children with disabilities. Marriage and Family Review, 20, 389-409.

Bradley, V. J. (1992). Overview of the family support movement. In V. J. Bradley, J. Knoll, \& J. M. Agosta (Eds.), Emerging issues in family support (pp. 1-8; Monographs of the American Association on Mental Retardation, No. 18). Washington, DC: American Association on Mental Retardation.

Breslau, N., \& Davis, G. C. (1986). Chronic stress and major depression. Archives of General Psychiatry, 43, 309-314.

Breslau, N., \& Prabucki, K. (1987). Siblings of disabled children: Effects of chronic stress in the family. Archives of General Psychiatry, 44, 1040-1046. 
Breslau, N., Staruch, K. S., \& Mortimer, E. A. (1982). Psychological distress in mothers of disabled children. American Journal of the Disabled Child, $136,682-686$.

Bristol, M. M. (1984). Family resources and successful adaptation to autistic children. In E. Schopler \& G. B. Mesibou (Eds.), The effects of autism on the family (pp. 289-310). New York: Plenum.

Bristol, M. M., Gallagher, J. J., \& Schopler, E. (1988). Mothers and fathers of young developmentally disabled and nondisabled boys: Adaptation and spousal support. Developmental Psychology, 24, 441-451.

Bromley, B., \& Blacher, J. B. (1991). Parental reasons for out-of-home placement of children with severe handicaps. Mental Retardation, 29, 275-280.

Brown-Gorton, R., \& Wolery, M. (1988). Teaching mothers to imitate their handicapped children: Effects on maternal demands. Journal of Special Education, 22, 97-107.

Burton, S. L., \& Parks, A. L. (1994). Self-esteem, locus of control, and career aspirations of college-age siblings of individuals with disabilities. Social Work Research, 18, 178-185.

Detrick, S. (Ed.). (1992). The United Nations Convention on the Rights of the Child: A guide to the. "Travaux Preparatoires." Boston: Martinus Nijhoff.

Drimmer, J. C. (1993). Cripples, overcomers, and civil rights: Tracing the evolution of federal legislation and social policy for people with disabilities. UCLA Law Review, 40, 1341-1410.

Girolametto, L. E. (1988). Improving the social-conversational skills of developmentally delayed children: An intervention study. Journal of Speech and Hearing, 53, 156-167.

Gittler, J., \& Rennert, S. (1992). HIV infection among women and children and antidiscrimination laws: An overview. Iowa Law Review, 77, 1313-1388.

Gostin, L. O., \& Beyer, H. A. (Eds.). (1993). Implementing the Americans With Disabilities Act: Rights and responsibilities of all Americans. Baltimore: Brookes.

Harris, S. L., Carpenter, L., \& Gill, M. (1988). The family. In J. L. Matson \& A. Marchetti (Eds.), Developmental disabilities: A life span perspective (pp. 47-66). Philadelphia: Grune \& Stratton.

Harrold, M., Lutzker, J. R., Campbell, R. V., \& Touchette, P. E. (1992). Improving parent-child interactions for families of children with developmental disabilities. Journal of Behavior Therapy and Experimental Psychiatry, 23, 89-100.

Hernandez, D. J. (1995). Changing demographics: Past and future demands for early childhood programs. In R. E. Behrman (Ed.), The future of children: Vol. 5. Long term outcomes of early childhood programs (pp. 145160). Los Altos, CA: The Center for the Future of Children.

Hodapp, R. M., \& Krasner, D. V. (1995). Families of children with disabilities: Findings from a national sample of eighth-grade students. Exceptionality, 5, 71-81.

Hutchins, V. L., \& McPherson, M. (1991). National agenda for children with special health needs: Social policy for the 1990s through the 21 st century. American Psychologist, 46, 141-143.

Irving Independent School District v. Tatro 468 U.S. 883, (1984)

Johnson, K. A., \& McNulty, M. (1990). Assuring adequate health and rehabilitative care for the child: Articles 6, 23, 34 and 25. In C. Price Cohen \& H. A. Davidson (Eds.), Children's rights in America: U.N. Convention on the Rights of the Child compared with United States law (pp. 219-237). Chicago: American Bar Association Center on Children and the Law.

Kazak, A. E. (1987). Professional helpers and families with disabled children: A social network perspective. Marriage and Family Review, 11, 177-191.

Knoll, J. (1992). Being a family: The experience of raising a child with a disability or chronic illness. In V. J. Bradley, J. Knoll, \& J. M. Agosta (Eds.), Emerging issues in family support (pp. 9-56; Monographs of the American Association on Mental Retardation, No. 18). Washington, DC: American Association on Mental Retardation.

Kobe, F. H., Rojahn, J., \& Schroeder, S. R. (1991). Predictors of urgency of out-of-home placement needs. Mental Retardation, 29, 323-328.

Kramer, D. T. (1994). Legal rights of children (2nd ed., Vols. 1-3.). Colorado Springs, CO: Shepard's/McGraw-Hill.
Levine, M., \& Levine, A. (1970). A social history of the helping services: Clinic, court, school, and community. New York: Appleton-Century-Crofts.

Lobato, D., Barbour, L., Hall, L. J., \& Miller, C. (1987). Psychosocial characters of preschool siblings of handicapped and nonhandicapped children. Journal of Abnormal Child Psychology, 15, 329-338.

Marcenko, M. O., \& Meyers, J. C. (1991). Mothers of children with developmental disabilities: Who shares the burden? Family Relations, 40, 186-190.

Melda, K., \& Agosta, J. (1992). Results of a national study of family support: Families do make a difference. Salem, OR: Human Services Research Institute.

Melton, G. B. (1996). The child's right to a family environment: Why children's rights and family values are compatible. American Psychologist, 51, 1234-1238.

Miller v. Whitburn 10 F.3d 1315, 7th Cir. (1993)

Mills v. Board of Education 348 F. Supp. 866, D.D.C. (1972).

Murphy-Berman, V., \& Weisz, V. (1996). U. N. Convention on the Rights of the Child: Current challenges. American Psychologist, 51, 1231-1233.

Pahl, J., \& Quine, L. (1987). Families with mentally handicapped children. In J. Orford (Ed.), Treating the disorder, treating the family (pp. 39-61). Baltimore: Johns Hopkins University Press.

Parrott, M. E., \& Herman, S. E. (1987). Report on the Michigan family support subsidy program. Lansing: Michigan Department of Mental Health.

Pennsylvania Association for Retarded Children (PARC) v. Pennsylvania 334 F Supp. 1257 (E.D. Pa. 1971)

Resnick, M. B., Armstrong, S., \& Carter, R. L. (1988). Developmental intervention program for high-risk premature infants: Effects on development and parent-infant interactions. Journal of Developmental and Behavioral Pediatrics, 9, 73-78.

Roberts, R. N., Wasik, B. H., Casto, G., \& Ramey, C. T. (1991). Family support in the home: Programs, policy, and social change. American Psychologist, 46, 131-132.

Rothstein, L. F. (1988). Special education malpractice revisited. Educational Law Reporter, 43, 1249-1262.

Rothstein, L. F. (1992). Disabilities and the law. Colorado Springs, CO: Shepard's/McGraw-Hill.

Rothstein, L. F. (1994). Disabilities and the law. (Suppl.). Colorado Springs, CO: Shepard's/McGraw-Hill.

Rust v. Sullivan, 500 U.S. 173. (1991).

Spaulding, R., \& Morgan, S. B. (1986). Spina bifida children and their parents: A population prone to family dysfunction? Journal of Pediatric Psychology, 11, 359-374.

Sullivan v. Zebley 493 U.S. 521 (1990).

Taylor, S. J., Knoll, J. A., Lehr, S., \& Walker, P. M. (1989). Families for all children: Value-based services for children with disabilities and their families. In G. H. S. Singer \& L. K. Irvin (Eds.), Support for caregiving families: Enabling positive adaptation to disability (pp. 41-54). Baltimore: Brookes.

Taylor, S. J., Lakin, K. C., \& Hill, B. K. (1989). Permanency planning for children and youth: Out-of-home placement decisions. Exceptional Children, 55, 541-549.

Tomkins, A. J., \& Weisz, V. (1995). Social science, law, and the interest in a family environment for children with disabilities. Toledo Law Review, 26, 937-956.

Trivette, C. M., Dunst, C. J., Boyd, K., \& Hamby, D. W. (1995). Family-oriented program models, help-giving practices, and parental control appraisals. Exceptional Children, 62, 237-248.

United Nations General Assembly. (1989, November). Adoption of a convention on the rights of the child. (U.N. Doc. A/Res/44/25). New York: Author.

Vincent, L. J., \& Salisbury, C. L. (1988). Changing economic and social influences on family environment. Topics in Early Childhood Special Education, 8, 48-59.

Zetlin, A. G. (1990). Mentally retarded adults and their siblings. American Journal of Mental Deficiency, 91, 217-225. 